\title{
Undervisningsprogrammet Vivat: foran veivalg?
}

Ved Torild Å nestad

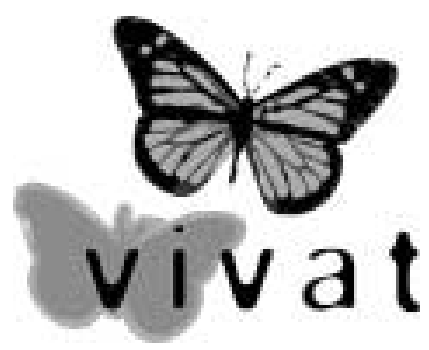

Vivat har utviklet seg fra å vaere et nord-norsk konsept til å bli et program som i dag er landsomfattende - etter bestilling fra sentrale helsemyndigheter ved etableringen av oppfølgingsprosjektet "Tiltak mot selumord" 2000-2002. Spredning av kurset og kompetanseoppbygging ble drevet frem av Vivats norske mor, Kirsti Silvola, sammen med en entusiastisk gruppe medarbeidere.

I dag anser vi pionértiden som avsluttet, og vi er over i driftsfasen. Det innebærer krav til dokumentasjon, organisasjonsstruktur og ledelse. Virksomhetsplanlegging blir viktig i denne sammenheng, også langtidsplanlegging. En svært viktig oppgave er å ta vare på kurslederne våre og sikre at de får oppfølging og fagl ig påfyll. U niversitetssykeh uset N ord-N orge ønsker å legge forholdene til rette for at Vivat kan ivareta sin nasjonale forpliktelse også i fremtiden.

Vivat er i dag administrativt underlagt U niversitetssykeh uset N ord- $\mathrm{N}$ orge H F, og lokalisert til Psykiatrisk forsknings- og utviklingsavdeling. Ettersom dette er et nasjonalt undervisningsprogram, har Vivat lønnede veiledere i hver helseregion.

Deres oppgave er først og fremst å støtte kursledere i sin region, og å være et bindeledd til prosjektleder. Etter hvert er det blitt så mange kursledere at det ikke lenger er mulig for lederen å ha direkte kontakt med den enkelte.

For å sikre at undervisningsprogrammet Vivat stadig utvikler og forbedrer seg, har en etablert et fagråd som ledes av overlege Kirsti Silvola. R ådet skal støtte leder i faglige spørsmål og skal ha ansvar for opplæring av nye kursledere.

U ndervisningsprogrammet Vivat har vært gjenstand for en omfattende revisjon. D et har medført at alt undervisningsmateriell er blitt oversatt til norsk. $\mathrm{H}$ østen 2003 ble nye kursledere lært opp etter den reviderte modellen. For å nå gamle kursledere, ble alle invitert til en stor samling på Lillestrøm i slutten av januar 2004, der det nye i kurset ble presentert. 0 ver 100 kursledere var med på denne samlingen, og Vivats ledelse var spent på om kurslederne følte seg trygge nok til å ta det nye opplegget i bruk. A t antall kurs har sunket i 2004, kan muligens være en indikator på at den reviderte utgaven oppleves vanskelig. Vi vil derfor øke innsatsen når det gjelder tilbud om veiledning til kursledere.

\section{Nye utfordringer}

A rbeidet med å implementere kurset F ørstehjelp ved selvmordsfare som en del av det faste undervisningstilbudet ved distriktspsykiatriske sentre eller psykiatriske sykehus vil få høy prioritet. Det er fortsatt slik at spesialisthel setjenesten har et lovpålagt ansvar for kompetanseoppbygging i forhold til primærhelsetjenesten. Videre tenker vi oss at kurset vil være særlig aktuelt for tverrfagl ige grupper i kommunene, sett i sammenheng med krav til sosial og helsemessig beredskap, og vi vil arbeide mål rettet mot dette.

I U SA og Canada er førstehjelpskurset del av den obligatoriske opplæringen i flere våpengrener i Forsvaret. H er i landet er det utdannet mange kursledere innen Forsvaret, men kursvirksomheten har ikke kommet skikkelig i gang ennå. Det vil derfor bli aktuelt å finne ut hvilke hindere som ligger i veien og om det er mulig å finne løsninger, slik at Forsvarets egne kursl edere kan komme på banen.

I oktober 2004 kom Ot.prp. nr. 1, statsbudsjettet. Her var Vivat nevnt spesifikt. Det innebærer at programmet blir finansiert også i 2005. I løpet av dette året har Sosial- og hel sedirektoratet lovt å foreta en evaluering av programmet. R esultatet av en slik evaluering vil være av betydning for V ivats fremtid, både organisatorisk og økonomisk.

Etter at oppfølgingsprosjektet "Tiltak mot selvmord" ble avsluttet i 2002, har det vært slitsomt og frustrerende også for Vivats stab ikkeå vite om videreføring før det kom klare signaler om det, enten i statsbudsjettet eller via Sosial- og helsedirektoratet - sent på året. Vivat er inne i driftsfase nå, men kan bare tilsette leder og medarbeidere i engasjementsstillinger. Takket være at U niversitetssykehuset $\mathrm{N}$ ord-N orge har bistått med garantier, har det lyktes å behol de kompetente fagfolk tilknyttet Vivat.

Vivats styringsgruppe har diskutert ulike forankringsmuligheter i fremtiden. U niversitetssykehuset $\mathrm{N}$ ord-N orge er det mest nærliggende og pr. dags dato det beste alternativet. Vivat har allerede etablert seg med deltidsstillinger i alle hel seregionene, og ser dette som svært gunstig med tanke på oppfølging av kursledere. Denne ordningen ønsker vi å videreføre i fremtiden, da i samarbeid med de regionale sentrene innen traumefeltet som er etablert eller skal etableres. D et vil likevel være behov for en sentral ledelse for et undervisningsprogram som er i stadig utvikling.

U tfordringene Vivat står ovenfor, er først og fremst å sikre videreføring på permanent basis i $\mathrm{N}$ orge. Vivat er et lavkostnadskonsept, har kompetent fagpersonell og et undervisningsprogram som gir reell handlingskompetanse også for personer uten helsefaglig bakgrunn.

Den store utfordringen vil bli etterspørselen fra utlandet. England, Skottland og N ord-Irland har kjøpt kurspakker fra Vivat. Vivat har vært med i U niversitetssykehuset N ord- $\mathrm{N}$ orges engasjement i A rkhangelsk. Litauen står foran en omfattende satsing på selvmordsforebygging, og Vivat er bedt om å bidra med opplæring av kursledere. Flere andre land i Europa har vist interesse for konseptet, og Living Works Education i Calgary ønsker at Vivat i N orge skal ha ansvar for kurs og kursl ederopplæring i Europa. Det stiller krav til organisasjonen, økonomisk og faglig. Det store spørsmålet er om lille Vivat kan påta seg forpliktelser utover $\mathrm{N}$ orge og bli et europeisk kompetansesenter. Fristen de, selvsagt - hvis vi kan venne oss til å drive butikk. For en eventuell satsing på Europa vil måtte basere seg på salg, dvs. at alle våre utgifter dekkes, inklusive administrasjon. Vil vi være klar for dette i løpet av de neste par årene?

Torild Å nestad
er leder av Vivat. H un har
vært prosjektleder for
"Tiltak mot selvmord" i
Rogaland og har arbeidet
med selvmordsproblematikk
siden begynnelsen av
1990-tallet.

